\title{
Composition and cross-sectional area of muscle fibre types in relation to daily gain and lean and fat content of carcass in Landrace and Yorkshire pigs
}

\author{
Marita Ruusunen \\ Department of Food Technology, P.O.Box 27, FIN-00014 University of Helsinki, Finland, \\ e-mail: marita.ruusunen@helsinki.fi \\ Marja-Liisa Sevon-Aimonen \\ Agricultural Research Centre of Finland, Institute of Animal Production, FIN-31600 Jokioinen, Finland \\ Eero Puolanne \\ Department of Food Technology, P.O.Box 27, FIN-00014 University of Helsinki, Finland
}

\begin{abstract}
The muscle fibre-type properties of longissimus were compared between Landrace and Yorkshire breeds and between the sexes in an attempt to shed light on the relationship of these histochemical parameters to animal growth and carcass composition. Muscle fibres were classified into three groups, type I, type IIA and type IIB, using the myosin ATPase method. At a given live weight, the crosssectional area of type I fibres $\left(\mathrm{CSA}_{1}\right)$ was smaller $(\mathrm{p}<0.01)$ and the cross-sectional area of type IIB fibres $\left(\mathrm{CSA}_{\mathrm{II}}\right)$ larger $(\mathrm{p}<0.01)$ in longissimus of Landrace than in that of Yorkshire. The CSA $(\mathrm{p}<0.01)$ was larger in gilts than in castrated males. At an average live weight of $97 \mathrm{~kg}$, the Landrace pigs were significantly younger $(\mathrm{p}<0.01)$ than the Yorkshire pigs. The $\mathrm{pH}_{1}$ value of Landrace was lower $(\mathrm{p}<0.01)$ than that of Yorkshire. The percentage of high-value cuts in carcass with head $(\mathrm{M} \%)$ was lower $(p<0.01)$ and the percentage of fat in back and loin $(F \%)$ higher $(p<0.01)$ in castrated males than in gilts. The cross-sectional area of loin $\left(\mathrm{CSA}_{\text {loin }}\right)$ was larger $(\mathrm{p}<0.01)$ in gilts than in castrated males. All the histochemical and other traits varied considerably between the animals. The correlations between histochemical properties and growth and histochemical properties and carcass composition were rather low.
\end{abstract}

Key words: pig breed, muscle fibre cross-sectional area, longissimus, carcass traits

\section{Introduction}

The pig breeds or crosses used for pork production tend to vary from country to country. The breeding goals also vary, and hence there may be genetic differences in the same breed between countries. The traditional pig breeds reared in Finland are Landrace and Yorkshire. Both have been bred intensively and separately for many years, although with similar breeding goals. The most important selection criteria in pig breed-

(ㄷ Agricultural and Food Science in Finland

Manuscript received September 1996 


\section{AGRICULTURAL AND FOOD SCIENCE IN FINLAND}

Ruusunen, M. et al. Composition and cross-sectional area of muscle fibre types

ing have been high daily gain and carcass leanness. Genetic selection is thought to influence muscle fibre composition by increasing the number and area of type II fibres in domestic pigs (Staun 1972, Swatland 1977, Rede et al. 1986). The muscles of wild pigs have a higher percentage of type I and type IIA fibres and a lower percentage of type IIB fibres than do domestic pigs, and also the CSA of muscle fibres is smaller in wild pigs than in domestic pigs at the same live weight (Bader 1983).

Muscle fibre composition affects both growth and lean meat content. Miller et al. (1975) found in longissimus and Dwyer et al. (1993) in semitendinosus that faster growing pigs appeared to possess more, but smaller, fibres than slower growing pigs at the same live weight. Staun (1972) and Miller et al. (1975) established that the total number of muscle fibres in longissimus was more closely related to muscle mass than was fibre diameter. Dwyer et al. (1993) reported similar results in their study on porcine semitendinosus. A positive correlation has also been found between the percentage of type IIB fibres in longissimus and the CSA of pork loin (Bader 1981, Fiedler and Otto 1982, Wegner and Ender 1990, Fewson et al. 1993). Tornberg et al. (1993) pointed out that in lean carcasses, the CSA of muscle fibres is larger than that in fat carcasses of the same weight.

This study sought to compare the histochemical properties of Finnish Landrace and Yorkshire breeds, to establish the differences in these properties between the sexes and also between pigs within the same breeds, and to investigate the relationships between these histochemical properties and animal growth and carcass composition.

\section{Material and methods}

The material consisted of 107 pure-bred pigs, 54 Finnish Landrace and 53 Yorkshire $(\mathrm{N}=53)$, raised at four different test stations. The proge- ny of 39 Landrace and 41 Yorkshire sires were used. The pigs were slaughtered at an average live weight of $97 \mathrm{~kg}$. Before slaughter, the pigs were allowed to rest overnight. They were then stunned with carbon dioxide. The day after slaughter, the left side of the carcass was dissected.

\section{Histochemical properties}

Muscle samples for histochemical analysis were taken from the right side of the carcass about 30-40 min after exsanguination from longissimus between the 13th and 14th ribs. The muscle sample, about $20 \mathrm{~g}$, was cut into pieces measuring $0.5 \times 0.5 \times 1.0 \mathrm{~cm}$, which were frozen in liquid nitrogen and stored at $-80^{\circ} \mathrm{C}$ until analysed.

The fibres were classified into three groups, type I, type IIA and type IIB, with the myosin ATPase method (Brooke and Kaiser 1970) and an acid preincubation solution ( $\mathrm{pH} 4.6$ ). Stained sections were examined with an image analysis system using CUE 2 Planomorphometry software (Olympus, Germany). The magnification was $160 \mathrm{x}$. The fibres were counted in an area of about $0.9 \mathrm{~mm}^{2}$, containing about $150-200$ fibres. Three different pieces of each muscle sample were stained, and thus 450-600 fibres were analysed. The following parameters were computed: percentage of type I (I\% number $)$, type IIA $\left(\mathrm{IIA} \%_{\text {number }}\right.$ ) and type IIB (IIB\% ${ }_{\text {number }}$ ) muscle fibres, percentage of the total area of type I $(\mathrm{I} \%$ area $)$, type IIA (IIA $\%_{\text {area }}$ ) and type IIB (IIB $\%_{\text {area }}$ ) muscle fibres, and the cross- sectional area of each fibre type $\left(\mu \mathrm{m}^{2}\right)\left(\mathrm{CSA}_{1}, \mathrm{CSA}_{\mathrm{IIA}}\right.$ and $\left.\mathrm{CSA}_{\mathrm{IIB}}\right)$.

The number of muscle fibres in longissimus per whole loin area $\left(\mathrm{Num}_{\text {fibre }}\right)$ was calculated as the loin area (at last rib) ( CSA $_{\text {loin }}$ ) divided by the average fibre cross-sectional area $\left(\mathrm{CSA}_{\text {fibre }}\right)$.

\section{Other traits}

The following station test traits were used in the study: age at slaughter (age), live weight at the end of the test (LW), average daily gain during 
Vol. 5 (1996): 593-600.

the test period adjusted to a weight of $25-100$ $\mathrm{kg}$ (ADG), carcass weight (CW), loin area at 13$14 \mathrm{rib}\left(\mathrm{CSA}_{\text {loin }}\right)$, percentage of fat in back and loin $(\mathrm{F} \%)$ and percentage of high-value cuts in carcass with head (M\%).

The $\mathrm{pH}$ value of longissimus was measured between the 13th and 14th ribs at $45 \mathrm{~min}\left(\mathrm{pH}_{1}\right)$ and $24 \mathrm{~h}\left(\mathrm{pH}_{2}\right)$ post mortem on each carcass (Knick Portamess pH meter 752 equipped with a Xerolyte electrode; Ingold Xerolyt LoT406M6, Germany).

\section{Statistical methods}

Data were analysed with the GLM procedure and the CORR procedure of the SAS/STAT program (SAS Institute 1990). The effects of breed and sex were studied using the following statistical model:

$$
\begin{aligned}
y_{i j k} & =u+\text { breed }_{i}+\operatorname{sex}_{j}+e_{i j k} \\
y_{i j k} & =\text { observation } \\
\mathrm{u} & =\text { overall mean } \\
\text { breed }_{\mathrm{i}} & =\text { effect of breed }(\mathrm{i}=1,2) \\
\operatorname{sex}_{j} & =\text { effect of sex }(\mathrm{j}=1,2) \\
\mathrm{e}_{\mathrm{ijk}} & =\text { residual term }
\end{aligned}
$$

The relationship between histochemical properties and animal growth and between histochemical properties and carcass composition was described with correlation coefficients. The effect of breed and sex was taken into account.

\section{Results and discussion}

\section{Difference in histochemical properties between breeds and sexes}

The muscle fibre composition of different breed has been compared in only a few studies. Here, longissimus of Landrace contained a significantly higher percentage of type I fibres and a lower percentage of type IIB fibres $(\mathrm{p}<0.01)$ than did that of Yorkshire (Table 1). The percentages of muscle fibre types of animals within both breeds varied, however, more than did those between the breeds on average. On the basis of histochemical properties, similar pigs can be found in both breeds. Miller and coworkers (1975) did not find any differences in fibre type composition in longissimus between Hampshire, Yorkshire and Hampshire x Yorkshire pigs, and Essen-Gustavsson and Fjelkner-Modig (1985) found none between Swedish Landrace, Yorkshire and Hampshire pigs. Here, no significant difference $(p>0.05)$ was found in fibre type composition between the sexes (Table 1).

At the same live weight, however, the $\mathrm{CSA}_{1}$ was smaller $(\mathrm{p}<0.01)$ in longissimus of Landrace than in that of Yorkshire, but the CSA $\mathrm{IIB}_{\text {was larg- }}$ er $(\mathrm{p}<0.01)$ (Table 1). In Danish Landrace-Yorkshire crossbred pigs the CSAs of type I and type IIB fibres were 2824 and $6120 \mu \mathrm{m}^{2}$, respectively at a live weight of $90 \mathrm{~kg}$ (Oksbjerg et al. 1990), and in Swedish Landrace-Swedish Yorkshire crossbred pigs 3200 and $5600 \mu^{2}$, respectively at a live weight of $100 \mathrm{~kg}$ (Essen-Gustavsson et al. 1992). The CSAs of different fibre types reported in various studies are difficult to compare because the muscle samples were excised from the carcasses at different times post mortem, and the CSA measurements were made on sections stained with different methods.

In this study, no significant difference was found in the estimated Num fibre $_{\text {between Landrace }}$ and Yorkshire or between sexes. The CSA $\left(5051 \mu \mathrm{m}^{2}\right)(\mathrm{p}<0.01)$ and the $\mathrm{CSA}_{\text {fibre }}\left(4476 \mu \mathrm{m}^{2}\right)$ $(\mathrm{p}<0.05)$ were larger in gilts than in castrated males (4593 and $4153 \mu \mathrm{m}^{2}$, respectively). Karlsson et al. (1994) also showed that the CSA of all fibre types was significantly smaller in longissimus of intact Yorkshire male pigs than in gilts at a live weight of $103 \mathrm{~kg}$.

\section{Difference in growth and carcass traits between breeds and sexes}

When pigs grow, the CSA of all fibre types grows as well, but the area of type IIA and type IIB is 


\section{Ruusunen, M. et al. Composition and cross-sectional area of muscle fibre types}

Table 1. The means and standard deviations of studied traits (mean \pm s.d.) of Landrace and Yorkshire breeds and of castrated males and gilts.

\begin{tabular}{|c|c|c|c|c|c|c|}
\hline & \multicolumn{2}{|c|}{ Breed } & \multicolumn{2}{|c|}{ Sex } & \multicolumn{2}{|c|}{ Statistical significance } \\
\hline & Landrace & Yorkshire & Castrates & Gilts & Breed & Sex \\
\hline Number of animals & 54 & 53 & 49 & 58 & & \\
\hline \multicolumn{7}{|l|}{ Histochemical traits } \\
\hline$I \%_{\text {number }}$ & $13.2 \pm 3.7$ & $9.9 \pm 3.8$ & $11.2 \pm 3.1$ & $11.8 \pm 4.8$ & ** & NS \\
\hline IIA\% $\%_{\text {number }}$ & $9.0 \pm 3.8$ & $8.6 \pm 3.1$ & $8.7 \pm 3.3$ & $8.9 \pm 3.7$ & NS & NS \\
\hline IIB $\%_{\text {number }}$ & $77.9 \pm 3.9$ & $81.6 \pm 3.8$ & $80.1 \pm 4.0$ & $79.3 \pm 4.5$ & $* *$ & NS \\
\hline $\mathrm{I} \%$ & $6.9 \pm 2.1$ & $6.4 \pm 2.4$ & $6.6 \pm 2.0$ & $6.7 \pm 2.5$ & NS & NS \\
\hline IIA $\%_{\text {area }}$ & $4.9 \pm 2.3$ & $5.3 \pm 2.0$ & $5.0 \pm 2.2$ & $5.2 \pm 2.2$ & NS & NS \\
\hline IIB $\%_{\text {area }}$ & $88.2 \pm 2.4$ & $88.3 \pm 2.6$ & $88.4 \pm 2.8$ & $88.1 \pm 2.2$ & NS & NS \\
\hline $\mathrm{CSA}_{1}, 1000 \mu \mathrm{m}^{2}$ & $2.4 \pm 0.5$ & $2.7 \pm 0.6$ & $2.4 \pm 0.5$ & $2.6 \pm 0.6$ & $* *$ & NS \\
\hline $\mathrm{CSA}_{\| \mathrm{A}}, 1000 \mu \mathrm{m}^{2}$ & $2.4 \pm 0.6$ & $2.6 \pm 0.5$ & $2.4 \pm 0.5$ & $2.5 \pm 0.5$ & NS & NS \\
\hline $\mathrm{CSA}_{1 \mathrm{IB}}, 1000 \mu \mathrm{m}^{2}$ & $5.1 \pm 0.9$ & $4.6 \pm 0.8$ & $4.6 \pm 0.7$ & $5.1 \pm 1.0$ & $* *$ & $* *$ \\
\hline $\mathrm{CSA}_{\text {fibre }}, 1000 \mu \mathrm{m}^{2}$ & $4.5 \pm 0.8$ & $4.2 \pm 0.6$ & $4.2 \pm 0.6$ & $4.5 \pm 0.8$ & $* *$ & $*$ \\
\hline Num $_{\text {fibre }}, 10^{6}$ & $0.97 \pm 0.16$ & $1.01 \pm 0.18$ & $0.99 \pm 0.15$ & $1.00 \pm 0.19$ & NS & NS \\
\hline \multicolumn{7}{|l|}{ Other traits } \\
\hline Age, d & $149 \pm 8$ & $155 \pm 8$ & $149 \pm 7$ & $154 \pm 8$ & $* *$ & $* *$ \\
\hline $\mathrm{LW}, \mathrm{kg}$ & $97.3 \pm 5.0$ & $97.1 \pm 3.8$ & $97.7 \pm 4.4$ & $96.7 \pm 4.7$ & NS & NS \\
\hline $\mathrm{ADG}, \mathrm{g}$ & $937 \pm 62$ & $929 \pm 66.1$ & $960 \pm 60.7$ & $910 \pm 67.8$ & NS & $* *$ \\
\hline $\mathrm{CW}, \mathrm{kg}$ & $71.3 \pm 4.1$ & $71.7 \pm 3.2$ & $71.4 \pm 3.4$ & $71.4 \pm 4.0$ & NS & NS \\
\hline $\mathrm{pH}_{1}$ & $6.28 \pm 0.24$ & $6.41 \pm 0.23$ & $6.36 \pm 0.24$ & $6.34 \pm 0.25$ & $* *$ & NS \\
\hline $\mathrm{pH}_{2}$ & $5.50 \pm 0.09$ & $5.51 \pm 0.13$ & $5.51 \pm 0.13$ & $5.50 \pm 0.10$ & NS & NS \\
\hline $\mathrm{CSA}_{\text {loin }}\left(\mathrm{cm}^{2}\right)$ & $42.4 \pm 4.5$ & $41.5 \pm 4.0$ & $40.3 \pm 3.3$ & $43.4 \pm 4.5$ & NS & $* *$ \\
\hline $\mathrm{M} \%, \%$ & $57.0 \pm 2.7$ & $56.6 \pm 2.2$ & $55.7 \pm 1.9$ & $57.7 \pm 2.5$ & NS & $* *$ \\
\hline $\mathrm{F} \%, \%$ & $20.0 \pm 3.2$ & $20.0 \pm 3.0$ & $21.4 \pm 2.6$ & $18.9 \pm 3.1$ & NS & $* *$ \\
\hline
\end{tabular}

NS = not significant, $\mathrm{p}>0.05{ }^{*}=$ significant, $\mathrm{p}<0.05 ;{ }^{* *}=$ significant, $\mathrm{p}<0.01$

$\mathrm{CSA}_{\text {fibre }}=$ cross-sectional area of fibre

$\mathrm{Num}_{\text {fibre }}=\mathrm{CSA}_{\text {loin }} / \mathrm{CSA}_{\text {fibre }}$

$\mathrm{ADG}=$ average daily gain $(\mathrm{g})$ during test period adjusted to weight of $25-100 \mathrm{~kg}$

$\mathrm{CSA}_{\text {loin }}=$ cross-sectional area of loin

$\mathbf{M} \%=$ percentage of high value cuts in carcass with head

$\mathrm{F} \%=$ percentage of fat in back and loin

affected the most. In this study, a positive correlation was found between $\mathrm{CSA}_{\text {IIB }}$ and age $(\mathrm{p}<0.05)$ but not between $\mathrm{CSA}_{1}$ or $\mathrm{CSA}_{\mathrm{IIA}}$ and age. The CSA of type IIB fibres could therefore be expected to increase more than the CSA of type I or type IIA fibres (Table 2). Fiedler et al. (1991) likewise found that the area of type IIB fibres increases more during growth than does the area of type I and type IIA fibres.

The average age, live weight, daily gain, carcass weight, $\mathrm{pH}_{1}$ and $\mathrm{pH}_{2}$ values, CSA of loin and $\mathrm{M} \%$ and $\mathrm{F} \%$ of the pigs studied in both breeds and sexes are given in Table 1. The Landrace pigs were significantly younger $(\mathrm{p}<0.01)$ when they reached the average live weight of 97 $\mathrm{kg}$ than were the Yorkshire pigs, although there was no significant difference in ADG between the breeds during the test period. The castrated males grew faster $(\mathrm{p}<0.01)$ than the gilts. The live weight was the same in both sexes, but $\mathrm{M} \%$ was lower $(\mathrm{p}<0.01)$ and $\mathrm{F} \%$ higher $(\mathrm{p}<0.01)$ in castrated males than in gilts (Table 1). Also, the $\mathrm{CSA}_{\text {loin }}$ was larger $(\mathrm{p}<0.01)$ in gilts than in castrated males. Similarly, in their study of German 


\section{AGRICULTURAL AND FOOD SCIENCE IN FINLAND}

Vol. 5 (1996): 593-600.

Table 2. Correlation coefficients between histochemical parameters and growth and between histochemical and carcass parameters.

\begin{tabular}{lccccccccc}
\hline & $\mathrm{Age}$ & $\mathrm{LW}$ & $\mathrm{ADG}$ & $\mathrm{CW}$ & $\mathrm{pH}_{1}$ & $\mathrm{pH}_{2}$ & $\mathrm{CSA}_{\text {loin }}$ & $\mathrm{F} \%$ & $\mathrm{M} \%$ \\
\hline $\mathrm{I}_{\text {number }}$ & .041 & .200 & .046 & .187 & .087 & .135 & .134 & .055 & -.079 \\
$\mathrm{IIA} \%_{\text {number }}$ & -.085 & -.178 & .020 & -.209 & .059 & .052 & -.034 & -.138 & .128 \\
$\mathrm{IIB} \%_{\text {number }}$ & .035 & -.035 & -.061 & .005 & -.133 & -.183 & -.099 & .073 & -.042 \\
$\mathrm{I} \%_{\text {area }}$ & .025 & .159 & .052 & .157 & .122 & .060 & .020 & .074 & -.125 \\
$\mathrm{IIA} \%_{\text {area }}$ & -.052 & -.071 & .038 & -.113 & .065 & .070 & .015 & -.164 & .161 \\
$\mathrm{IIB}_{\text {area }}$ & .020 & -.096 & -.076 & -.052 & -.185 & -.116 & -.029 & .073 & -.028 \\
$\mathrm{CSA}_{1}$ & .141 & .028 & .090 & .103 & .038 & -.070 & -.071 & .088 & -.178 \\
$\mathrm{CSA}_{\text {IIA }}$ & .173 & .331 & .175 & .341 & -.004 & .072 & .160 & .019 & -.019 \\
$\mathrm{CSA}_{\text {IIB }}$ & .222 & .148 & .045 & .202 & .046 & .060 & .114 & .060 & -.143 \\
$\mathrm{CSA}_{\text {fibre }}$ & .235 & .160 & .062 & .223 & .023 & .038 & .092 & -.090 & -.169 \\
Num $_{\text {fibre }}$ & -.103 & .008 & -.005 & .046 & -.012 & .001 & .493 & -.305 & .391 \\
\hline
\end{tabular}

${ }^{*}=$ significant, $\mathrm{p}<0.05 ;{ }^{* * *}=$ significant, $\mathrm{p}<0.001$

$\mathrm{CSA}_{\text {fiber }}=$ cross-sectional area of fibre

$\mathrm{Num}_{\text {fibre }}=\mathrm{CSA}_{\text {loin }} / \mathrm{CSA}_{\text {fiber }}$

$\mathrm{ADG}=$ average daily gain $(\mathrm{g})$ during test period adjusted to weight of $25-100 \mathrm{~kg}$

$\mathrm{CSA}_{\text {loin }}=$ cross-sectional area of loin

$\mathbf{M} \%=$ percentage of high value cuts in carcass with head

$\mathrm{F} \%=$ percentage of fat in back and loin

Landrace Nürnberg and Ender (1990) found that carcass meat content was lower, fat content higher and the cross-sectional area of loin smaller in castrated males than in gilts at the same live weight.

The $\mathrm{pH}_{1}$ value of Landrace was lower $(\mathrm{p}<0.01)$ than that of Yorkshire pigs (Table 1.) On the basis of $\mathrm{pH}_{1}$ values $(<5.8)$, there were only two PSE carcasses among the pigs studied, one in each breed. This is a very low number $(1.3 \%)$, due possibly to the fact that the pigs were always allowed to rest overnight before slaughter. The $\mathrm{pH}_{1}$ value found here was lower and the $\mathrm{CSA}_{\text {IIB }}$ larger in Landrace than in Yorkshire pigs.
A large fibre CSA may result in limited diffusion of muscle lactate into blood in stress situations. Lactate can thus rapidly accumulate in the muscle and give rise to low $\mathrm{pH}$ values. In porcine longissimus, glycogen is normally stored in type IIB fibres (Swatland 1975, Karlsson et al. 1994). If the content of type IIB fibres is high and that of type I fibres in longissimus low, there is also a high glycogen content, and thus more lactate may be formed. In dark porcine muscles with a high content of type I fibres it is impossible for the ultimate $\mathrm{pH}$ value to go as low as in light muscles because of the lower glycogen stores in dark muscles. Neither in this study nor 


\section{AGRICULTURAL AND FOOD SCIENCE IN FINLAND}

Ruusunen, M. et al. Composition and cross-sectional area of muscle fibre types

in the work of Nürnberg and Ender (1990) were any significant differences found in $\mathrm{pH}_{1}$ or $\mathrm{pH}_{2}$ values between the sexes.

\section{The relation of histochemical properties to growth and carcass parameters}

The correlation coefficients for growth and carcass traits and for the histochemical parameters measured for porcine longissimus are listed in Table 2. The finding of Sosnicki (1987) that a negative correlation exists between the percentage of BR fibres and age was not confirmed here $(p>0.05)$. Nor was our study able to confirm the finding of Miller et al. (1975) that faster growing pigs appeared to possess more, but smaller, fibres in longissimus than did slower growing pigs at the same live weight. We did, however, find a positive correlation between $I \%_{\text {number }}$ and LW $(\mathrm{p}<0.05)$ and between $\mathrm{CSA}_{\mathrm{IIA}}$ and LW $(\mathrm{p}<0.001)$, and between $\mathrm{CSA}_{\mathrm{IIA}}$ and $\mathrm{CW}$ $(\mathrm{p}<0.001)$ and between $\mathrm{CSA}_{\mathrm{IIB}}$ and CW $(\mathrm{p}<0.05)$. We also found a negative correlation between IIA $\%_{\text {number }}(\mathrm{p}<0.05)$ and CW. The positive correlation between live weight and ADG ( $r=.414$, $\mathrm{p}<.001$ ) makes it difficult to come to any definite conclusion regarding the relationship between histochemical parameters and growth rate. Some researchers have found a positive correla- tion between the percentage of type IIB fibres in longissimus and the CSA of pork loin (Bader 1981, Fiedler and Otto 1982, Wegner and Ender 1990, Fewson et al. 1993), but we could not confirm this finding $(\mathrm{p}>0.05)$. Our findings were, however, consistent with those of Staun (1972) and Miller et al. (1975), namely that a positive correlation exists between the $\mathrm{Num}_{\text {fibre }}$ and $\mathrm{CSA}_{\text {loin }}$ and between the Num $\mathrm{fibre}_{\text {and }}$ M\%. A negative correlation was found between Num $_{\text {fibre }}$ and $\mathrm{F} \%$.

\section{Conclusions}

Comparisons of all histochemical traits reveal significant variance between animals. Landrace longissimus shows a lower number of type IIB fibres with a larger fibre CSA than does Yorkshire longissimus. The CSA of type IIB fibres is larger in gilts than in castrates. There are differences in growth and carcass parameters between the sexes. The large variation in histochemical and other traits between animals suggests that it should be possible to select animals with the desired characteristics for breeding. Further investigations are needed to establish the criteria for good meat quality parameters and the heritability of these properties.

\section{References}

Bader, R. 1981. Enzymhistochemische, histometrische, histologische und elektronenmikroskopische Untersuchungen an der Skelettmuskulatur gesunder ausgemästeter Schweine der deutschen Landrasse in unterschiedlichen Haltungssystemen. Berlin, Freie Universität, Fachbereich Veterinärmed. 192 p. Diss.

- 1983. Vergleichende histometrische und histologische Untersuchungen an der Skelettmuskulatur von Wild- und Hausschweinen. Berliner und Münchener Tierărztliche Wochenschrift 96: 89-97.

Brooke, M. H. \& Kaiser, K. K. 1970. Muscle fibre-types: How many and what kind? Archives of Neurology 123: 369-379.

Dwyer, C.M., Fletcher, J.M. \& Stickland, N.C. 1993.
Muscle cellularity and postnatal growth in the pig. Journal Animal Science 71: 3339-3343.

Essen-Gustavsson, B. \& Fjelkner-Modig, S. 1985. Skeletal muscle characteristics in different breeds of pigs in relation to sensory properties of meat. Meat Science 13: $33-47$.

- , Karlström, K. \& Lundström, K. 1992. Muscle fibre characteristics and metabolic response at slaughter in pigs of different halothane genotypes and their relation to meat quality. Meat Science 31: 1-11.

Fewson, D., Rathfelder, A. \& Müller, E. 1993. Untersuchungen über die Beziehungen von Fleischanteil, Fleischbeschaffenheit und Stressresistent bei verschiedenen Schweineherkūnften. Züchtungskunde 65: 284-296. 
Vol. 5 (1996): 593-600.

Fiedler, I. \& Otto, E. 1982. Anzahl und Grösse der Muskelfasertypen in $M$. longissimus dorsi von Schweinen in ihrer Beziehung zu Merkmalen des Schlachtkörperwertes. Fleisch 36: 213-214.

- , Wegner, J. \& Feige, K.-D. 1991. Ein Wachstumsmodell für den Faserdurchmesser in zwei Muskeln des Schweines. Archiv für Tierzucht 34: 57-62.

Karlsson, A., Essen-Gustavsson, B. \& Lundström, K. 1994. Muscle glycogen depletion pattern in halothanegene-free pigs at slaughter and its relation to meat quality. Meat Science 38: 91-101.

Miller, L.R., Garwood, V.A. \& Judge, M.D. 1975. Factors affecting porcine muscle fibre type, diameter and number. Journal Animal Science 41: 66-77.

Nürnberg, K. \& Ender, K. 1990. Die Fettqualität bei Schweinen unterschiedlichen Geschlechtes. Fleischwirtschaft 70: 1099-1102.

Oksbjerg, N., Blackhaw, A., Henckel, P., Fernandez, J. A. \& Agergaard, N. 1990. Alterations in protein accretion and histochemical characteristics of the $M$. longissimus dorsi in pigs caused by Salbutamol (a $\beta$-adrenergic agonist). Acta Agriculturae Scandinavica 40: 397-401.

Rede, R., Pribisch, V. \& Rahelic, S. 1986. Untersuchungen über die Beschaffenheit von Schlachttierkörpern und Fleisch primitiver und hochselektierter Schweinerassen. Fleischwirtschaft 66: 898-907.
SAS Institute. 1990. SAS/STAT User's Guide, Version 6, Fourth Edition. SAS Institute Inc., Cary, N.C.

Sosnicki, A. 1987. Histopathological observation of stress myopathy in $M$. longissimus in the pig and the relationship with meat quality, fattening and slaughter traits. Journal of Animal Science 65: 584-596.

Staun, H. 1972. The nutritional and genetic influence on number and size on muscle fibres and their response to carcass quality in pigs. World Review of Animal Production 8: 18-26.

Swatland, H.J. 1975. Relationship between mitochondrial content and glycogen distribution in porcine muscle fibres. Histochemical Journal 7: 459-469.

- 1977. Histochemical changes during muscle growth in pigs. Zentralblatt für Veterinărmedizin, A. 24: 248-251.

Tornberg, E., Andersson, A., Göransson, Å. \& von Seth, G. 1993. Water and fat distribution in pork in relation to sensory properties. In: Puolanne, E. et al. (eds.). Pork Quality: Genetic and Metabolic Factors. Papers presented at an OECD workshop in Helsinki, Finland, June 8-10, 1992. p. 239-256.

Wegner, J. \& Ender, K. 1990. Mikrostrukturelle Grundlagen des Wachstums von Muskel- und Fettgewebe und die Beziehung zu Fleischansatz und Fleischbeschaffenheit. Fleischwirtschaft 70: 337-340. 


\section{AGRICULTURAL AND FOOD SCIENCE IN FINLAND}

Ruusunen, M. et al. Composition and cross-sectional area of muscle fibre types

\section{SELOSTUS}

\section{Lihassolutyypin ja lihassolun poikkipinta-alan yhteys sian kasvuun ja ruhon koostumukseen maatiaisessa ja yorkshiressa}

Tutkimuksessa verrattiin maatiais- ja yorkshire-sikarotuja keskenään määrittämällä histokemiallisesti longissimus-lihaksen lihassolutyyppien ominaisuuksia. Lisäksi selvitettiin histokemiallisten ominaisuuksien suhdetta eläimen kasvuun ja ruhon laatuun. Käsiteltävinä muuttujina olivat ikä, päiväkasvu, elopaino, teuraspaino, $\mathrm{pH}_{1}$ - ja $\mathrm{pH}_{2}$-arvot, ulkofileen poikkipinta-ala sekä ruhon liha- ja rasvaprosentit. Lihassolut määritettiin myosiini ATPaasimenetelmällä ja luokiteltiin kolmeen ryhmään: I, IIA ja IIB. Lihassolujen lukumäärä laskettiin jakamalla fileen poikkipinta-ala keskimääräisellä lihassolun poikkipinta-alalla.

Maatiaisen longissimus-lihaksessa oli tyypin I lihassolujen poikkipinta-ala pienempi ja tyypin IIB li- hassolujen poikkipinta-ala suurempi kuin yorkshiren longissimus-lihaksessa. Leikkojen longissimus-lihaksessa tyypin IIB lihassolut olivat suurempia kuin imisien longissimus-lihaksessa. Rotu ja sukupuoli eivät vaikuttaneet ulkofileen lihassolujen määriin. Maatiaisessa $\mathrm{pH}_{1}$-arvot olivat alhaisempia kuin yorkshiressa. Imisissä oli ruhon lihamäärä suurempi ja rasvamäärä pienempi kuin leikoissa. Myös ulkofileen poikkipinta-ala oli imisissä suurempi kuin leikoissa. Eri eläinyksilöiden histokemialliset, kasvu ja ruhon laatuominaisuudet vaihtelivat paljon. Histokemialliset ominaisuudet eivät vaikuttaneet eläimen kasvuun ja ruhon laatuominaisuuksiin. 